\section{Tragedy: then and now}

\section{Opinion}

Please don't expect me to begin with a comprehensive definition of tragedy. There are tragedies and tragedies. Remember the words of Polonius in Hamlet (II.ii.393-97): ...tragedy, comedy, history, pastoral, pastoral-comical, historical-pastoral, tragical-historical, tragical-comical-historical-pastoral, scene individable, or poem unlimited. Any attempt to provide an omnibus definition of tragedy will prove futile. Some of you may cite as examples quite a few plays which do not fit into any single definition. Jan Kott once thought that he "could discover the smallest structural unit of tragic opposition: trageme, like Levi-Strauss's mytheme shaped after the pattern of linguistic phoneme and morpheme." $\mathrm{pi}$ He found such instances of the trageme in the killing of the mother to avenge the murdered father, the burying of a brother at the price of one's own death, an involuntary "fate-bound" crime for which one has to bear full responsibility. ${ }^{1}$ Apparently Kott had the Oresteian trilogy of Aeschylus, and Antigone and King Oedipus of Sophocles in mind. But there are other tragedies, even in Greek, not to speak of English, French and German, which can provide other similar tragemes. We can, however, assume that there is a special kind of play called tragedy, which is serious in intent and portrays suffering often of a high degree. As you may well understand, I have taken both the ideas (seriousness and suffering) as the basic constituents of tragedy from Aristotle's Poetics. In his definition of tragedy, Aristotle first mentions high seriousness (spoudaioas) as a characteristic element of this kind of play (6.2). The second element, suffering (pathos) is declared to be a part of the plot (11.6). These two elements, I believe, may be taken as the common denominator of all tragedies. But, as to the effect produced by reading or viewing a tragedy, no consensus has emerged or is expected to emerge. Whether a tragedy evokes pity (eleos) and terror (phobos) (as Aristotle says), or admiration and commiseration (as Sidney declares), or as the central feeling the impression of waste (as Bradley proposes) is an issue I would not venture to go into. In our undergraduate days we had to read Edmund Burke's Speech on Conciliation with America (1775). One sentence from that text (echoing Milton's Paradise Lost, 2.59294), still rings in my ear: "Beware of the Serbonian bog where whole armies have sunk." ${ }^{\text {ii }}$ Catharsis (i.e. reader/audience response) is such a bog.

I, therefore, propose a rather loose description of the term, tragedy, and in keeping with the generally accepted view that tragedy flourished pre-eminently in two epochs: first, in Periclean Athens in the fifth century BCE and second, in Elizabethan England in the sixteenth century culminating in Shakespeare in the early seventeenth century. There is a gap of more than two millennia between the two ages. In the mean time tragedy as a dramatic form went into hibernation. Even the concept of tragedy underwent a sea change. While describing what tragedy is, Chaucer in his Monk's Tale refers not to a particular kind of play, but to a story, either in verse or in prose which has the following pattern:

Tragedy means a certain kind of story,

As old books tell, of those who fell from glory,

\section{${ }^{\mathrm{i} K o t t, p . X V I I}$}

iiLake Serbonis, now dried up in the North East corner of Egypt, was often covered with sand. When Darius Ocheus invaded Egypt a part of his troops was swallowed up in this lake.
Volume 3 Issue 2 - 2019

\section{Ramkrishna Bhattacharya}

Pavlov Insitute, 98 Mahatma Gandhi Road, Kolkata 700 007, India

Correspondence: Ramkrishna Bhattacharya, Pavlov Insitute, 98 Mahatma Gandhi Road, Kolkata 700 007, India,

Email ramkrishna.bhattacharya@gmail.com

Received: February 07, 2019| Published: March 18, 2019

People that stood in great prosperity

And were cast down out of their high degree

Into calamity, and so they died.

(From the modernized version by Nevill Coghill)

This is important, for when we come to the studies on modern tragedy, we find that the idea of tragedy is not confined to drama. W. H. Auden contrasts Captain Ahab's doom in Hermann Melville's Moby Dick (1851) with its classical Greek prototype. ${ }^{\text {iii }}$ Raymond Williams includes Leo Tolstoy, D. H. Lawrence and Boris Pasternak, in Modern Tragedy $(1964,1979)$ although George Steiner preferred to confine himself to drama alone in The Death of Tragedy. ${ }^{2}$ The dissimilarities between Greek and Elizabethan tragedies are only too apparent to need elaboration. I will not try to enumerate all the external features that distinguish Shakespeare from Sophocles. Suffice it to say that both of them were tragedians, not because they followed the same mode of construction but because both could move the audience in their own times and do still now. Both induced their readers to plumb the hidden depths of human mind. That is where their similarity ends.

The cardinal feature of Greek tragedy is that it is rooted in myth. Myth is the quarry of the tragemes of Aeschylus, Sophocles and Euripides. Elizabethan tragedy, on the other hand, drew upon the annals and chronicles of Rome, England and Scandinavia for their plot. Tragedy thus broke away from its mythological moorings. In short we may call this process "demythologization". Demythologization does not imply that the tales connected with the Greek gods and heroes were replaced with Biblical stories. Demythologization also entailed secularization. Tragedy, it has been claimed, is alien to the Judaic sense of the world. The same might be said of Christianity. There is always a hope for redemption, for God's grace can save even the worst sinner. But such a view may not be acceptable to all. W. H. Auden described Captain Ahab as a "Christian tragic hero". Good Christians have written profound tragedies. Their religious belief did not interfere with the themes they had chosen. In any case it is found that human agency and objective conditions assume a leading role in postElizabethan tragedy. A distinctly secular view of tragedy has come to replace the older view which reserved some room for predestination and the caprice of the gods. The development of tragedy since the eighteenth century points to this radical change of focus.

Here I must pause a while. Is there anything called tragedy in modern times, more particularly, after the eighteenth century? Do we any longer use the label, 'tragedy' in discussing the plays of recent times? Steiner was of the opinion that old tragic forms were no longer appropriate "to the rational, optimistic and sentimental temper of post-

iii Auden in: Abel (ed.), pp.40-44. 
Pascalian man." iv He himself, however, was not very sure whether tragedy was really dead. He concluded his work with the remark that there was still a remote possibility that the tragic theatre might have before it a new life and future. ${ }^{v}$ Raymond Williams, however, was never in doubt regarding the vitality of tragedy. His Modern Tragedy traces the development of tragedy from Lessing to Brecht. Whether we apply the term 'tragedy' or not, there are enough modern serious plays with suffering as their theme. And the concept of post-Pascalian man gives more credit to Blaise Pascal (1923-1662) than is due to him. His ideas did not cause any paradigm shift comparable to the Copernican revolution and the theories of Darwin and Freud and Marx.

Steiner also suggests that the ideal of tragedy was challenged from two quarters in the nineteenth century: (a) the spread of realistic prose due to the emergence of the novel as a new literary form, and (b) the opera which put forward "a serious claim to the legacy of tragic drama." ${ }^{\text {vi3-5 }}$

The second point is worth pondering. The opera of Mozart (17561791) and Wagner (1813-1883) did absorb much of the elements of old tragedy, but tragedy itself did not disappear. Prose tragedy in fact is an offshoot of the process of democratization going on in the body politic of Western Europe. We shall now move to this issue. We are generally more familiar with the English dramatic tradition. But the fact is that, tragedy after the sixteenth century flourished more on the continent than in the small group of islands now known as the United Kingdom. The names of Corneille and Racine, Goethe and Schiller, Ibsen and Chekhov and, last but not least, Bertolt Brecht are enough to support this view. ${ }^{6}$ In their hands tragedy underwent another transformation, namely, democratization. Gone were the kings and princes, whose fall had provided the staple for tragedy in the ages. Aristotle remarks that ... at first the poets treated any stories that came to hand, but nowadays the best tragedies are written about a handful of families, ...(13.5). He refers to the families of Oedipus, Orestes and the like "whom, it has befallen to suffer or inflict terrible experiences." Elizabethan dramatists, too, chose men of eminence (kings, princes, generals, etc.) who had to suffer exceptional misfortune. The heroic tragedy of the Restoration Period did not deviate from this formula. ${ }^{7,8}$

Incidentally, I would like to point out that the concept of the "tragic hero" is not really Aristotelian. There is, of course, a Greek word, heros, from which the English word, 'hero' is ultimately derived. In Homer the meaning of heros is not restricted to warriors but includes all free men of that age, including the minstrel, the herald, the leech (i.e. the quack), etc. In Hesiod, however, the heroes belong to the Fourth Age of man who were definitely superior to the present race (Works and Days, lines 156-60). In Pindar heros stands for a race between gods and men, rather demigods, as in Hesiod (whether born of one divine parent or, like Theseus, benefactors of mankind). Aristotle never uses the word heros in the Poetics. By character, ethos, he means the protagonist of any play. The concept of the tragic hero is actually a modern invention. Lucas $\mathrm{DW}^{9}$ tells us:

In fact no such term [as hero] existed until the sixteenth century when the Italian commentators on the $P[$ Poetics $]$ made the transition from heroes, i.e. figures from the heroic age (heroikoi chronoi, Pol. [Politics] 1285b4) who are the normal subject of tragedy to the most conspicuous of them in any one play, the 'hero'. He was taken over from them in France by Boileau and first appears in English in

\footnotetext{
${ }^{\text {iv }}$ Steiner, p.4.

v'bid., p.175.

vilbid., p.284.
}

Dryden's Defence of the Epilogue in 1673. ${ }^{\text {vii }}$ Lucas further points out that "the Elizabethans had indubitable heroes, though they had no words for them."

Let us go back to the topic of democratization.

Right from the eighteenth century the concept of tragedy came to be applied to the hoi polloi, the commoners. Suffering has been the badge of their kind since times immemorial. But the more aesthetically oriented critics insisted on keeping life and literature in two separate compartments. Filial ingratitude could very well be the theme of a tragedy, but the victim has to be a king, even though Lear, who suffers, is no longer so. However, the spread of new ideas following the Enlightenment, and, more particularly the French Revolution of 1789 , put an end to the aristocratic bias that had been part and parcel of the magnitude of tragic effect. With the abolition of monarchy along with other feudal privileges in many countries, the idea of the equality of man came to influence the dramatists as well. Maurya in Synge's play, Riders to the Sea, could now appear as another Hecuba, the Trojan Queen. Her suffering is no less than Niobe's, the legendary Greek woman who lost her children one by one, all due to a God's wrath.

We shall conclude with another notable feature of modern tragedy: the shift of emphasis from destiny and/or character to mundane, external circumstances. The real tragedy of Roberts in Galsworthy's Strife (1909) does not lie either so much in his character or in the decision taken by some superhuman power which intended to punish him for some sin he had committed as in the compulsion of external circumstances. This feature we may tentatively call, in the style of earlier terms, "objectivization" (pardon the neologism). Unfavourable objective circumstances make Falder in Galsworthy's Justice (1910) forge a cheque and repeat the act even after his release from jail. This is not viewed as a kind of pathological case. On the contrary, Galsworthy hints at the adverse social and economic forces and the inhumanity of the prison system that turned Falder into a confirmed "criminal". Such a view was unknown to the Greeks and would have been inconceivable to the Elizabethans. It could be possible only in a modern society that had outgrown the ideas of divine dispensation and the privilege of high birth. Modern tragedy no longer blames the individual alone but focuses on the pressure of socio-economic circumstances on persons who are unable to cope with them. Hence there is scarcely a villain in modern tragedy. There is a clear shift from the subjective to the objective.

\section{Acknowledgments}

Amitava Bhattacharyya, Debapriya Pal.

\section{Conflicts of interest}

The author declares that there is no conflict of interest.

\section{References}

1. Kott, Jan. The Eating of the Gods: An Interpretation of Greek Tragedy. London: Eyre Methuen. 1974.

2. Steiner, George. The Death of Tragedy. London and Boston: Faber and Faber. 1978 (first published 1961).

3. Abel, Lionel. Moderns on Tragedy. New York: Fawcett World Library. 1967.

\footnotetext{
viiLucas, p.140.
} 
4. Williams, Raymond. Modern Tragedy. London: Verse. 1979.

5. Baldick, Chris. The Concise Oxford Dictionary of Literary Terms Oxford and New York, Oxford Uni. Press. 1990.

6. Brecht, Bertolt. Collected Plays. Vol.V. New York: Vintage Book. 1972.
7. Dorsch TS. Aristotle's Poetics in Classical Literary Criticism. Harmondsworth: Penguin Books. 1965.

8. Leech, Clifford. Tragedy. London and New York: Methuen. 1969.

9. Lucas DW. Aristotle. Poetics. Oxford: Clarendon Press. 1988 (first published 1968). 